\title{
Die klassis en kerkvisitasie in drie kerkordes
}

Author:
Piet J. Strauss ${ }^{1}$
Affiliation:
${ }^{1}$ Faculty of Theology,
University of the Free State,
Bloemfontein, South Africa
Corresponding author:
Piet Strauss,
straussp@ufs.ac.za
Dates:
Received: 05 June 2017
Accepted: 20 July 2017
Published: 29 Sept. 2017
smart phone or
mow to cite this article:
Strauss, P.J., 2017, 'Die klassis
en kerkvisitasie in drie
kerkordes' In die Skriflig
51(1), a2282. https://doi.
org/10.4102/ids.v51i1.2282
Conead online:
Copyright:
C 2017. The Authors.
Licensee: AOSIS. This work
is licensed under the
Creative Commons
Attribution License.

The classis and the visitation of congregations in three church orders. It is said by reformed church politicians that the classis as a major assembly in reformed church polity is the cornerstone of the church as a denomination. In the tradition in which the church order of the wellknown Synod of Dordrecht of 1618-1619 plays an important role, the classis is used as an assembly of local congregations caring for one another and helping to become better churches. This means that the visit of a commission of the classis to a congregation to care for it should be of a pastoral nature. The pastoral caring and advice of the classis should enable a congregation to become a better church. The members of this commission are, however, not rated as superior or more important ministers. The acceptance of their competent advice by equals helps the latter only to fulfil their ecclesiastical calling.

\section{Inleiding}

Die klassis, of die ring soos dit in die NG Kerk gebruik word, is volgens sekere gereformeerde kerkregtelikes 'n baie belangrike kerklike vergadering.

Gemeet aan sy funksies soos bepaal in die Kerkorde van die NG Kerk (NGKO 1964), noem Kleynhans (1985:51) die ring 'feitlik die hartaar van die kerkverband'. Hy gebruik daarvoor die uitdrukking "n baie belangrike vergadering'.

As die 'eerste' of 'naaste-aan-die-gemeentes meerdere vergadering van gemeentes in kerkverband' ons kom daarop terug - praat Kruger et al (1966:29) van die klassis as die 'belangrikste meerdere vergadering ... waarop die omvattendste werkprogram afgehandel word'. Spoelstra (1989:248) noem die klassis die 'belangrikste meerdere vergadering in presbiteriale kerkreg'.

Op sy beurt wys Van den Broeke in 2010 daarop dat die Duitse kerkhistorikus J.F.G. Goeters, by die 400-jarige herdenking van die Konvent van Wesel (1568) in 1968 aangetoon het dat hierdie eerste Konvent in gereformeerde Nederland die klassis as 'n belangrike instelling vir die toekoms beskou het. Die klassis het as 'n vergadering van die gemeentes van die omgewing (hulle naaste meerdere vergadering) in die Nederlandse gereformeerde kerkverband by die Nasionale Sinode van Emden in 1571 praktiese beslag gekry (Van den Broeke 2010:10,13; acta aangehaal deur Pont $1981: 75,104)$.

Van den Broeke (2010:10) kry deesdae egter die indruk dat talle kerke die klassis as argaïes, vervelig, stowwerig en onbruikbaar beskou. Hierteenoor haal hy (2010:10) A. Th. van Deursen aan wat in 1998 beweer dat die klassis belangrik bly vanweë sy gesag of potensiële impak in die omgewing. Hy wys ook op H. Noordzij wat aan die klassis 'n 'central position' ten opsigte van reformasie in die Nederlandse gereformeerde kerke toeken.

Hierdie waardering van die ring of klassis by skrywers moet gesien word teen die agtergrond van die gebruik van klasses of ringe, streek- of partikuliere sinodes en algemene of generale sinodes as vergaderings van meer gemeentes in 'n gereformeerde kerkverband. Meerdere vergaderings het elk 'n eie doel of funksie (vgl. NGKO 2013:6-12) waarin die klassis op sy terrein prinsipieel selfstandig teenoor ander kerkvergaderings is. Hierdie vergaderings is elkeen vanweë hulle spesifieke doel, kerklik belangrik.

By kerke in die Dordtse of Nederlandse gereformeerde kerkordelike tradisie, waarvan die Konvent van Wesel (1568) met sy artikels die begin- en die Dordtse Sinode (1618-1619) met sy Kerkorde (DKO) die kulminasiepunt was (Rutgers 1971:10; Strauss 2010:7-8), ${ }^{1}$ is kerkverband 'n

1.Koffeman (2009:71) wys daarop dat die reformatoriese kerkordelike benadering as "het presbyteriaal-synodale stelsel" gebuik word in die oorgrote deel van die kerke in Nederland wat hulle in die 'calvinistische traditie' bevind. Hieronder plaas hy onder andere die Protestanse Kerk in Nederland, die Christelike Gereformeerde Kerke, die Gereformeerde Kerke (Vrygemaak) en die Gereformeerde Gemeentes. 
sinodale verband waarin die naburige gemeentes in klasses (meervoud) saamkom. Die Konvent van Wesel (1568) noem die klassis 'n vergadering van 'naburige kerken' of gemeentes en vestig daarmee hierdie norm in die Nederlandse gereformeerde kerklike tradisie (acta aangehaal in Pont 1981:134).

Die mees gebruiklike benaming by kerkverbande in die Nederlandse gereformeerde tradisie vir die vergadering van naburige gemeentes of kerke, is klassis. Haitjema (1951:130) toon aan dat die gereformeerde kerkreg in die 'klassieke tijd' van Calvyn in Genève en Johannes a Lasco in Oos-Friesland ook 'n 'ring' of 'coetes' geken het, maar dan as 'n subklassikale verband van gemeentes. Die ringe het nie deel aan die regering deur meerdere vergaderings gehad nie, maar hulle 'geestelijke energie' vir die gemeenskaplike 'aktiviteits-ontplooiing' van die betrokke gemeentes gebruik. Hulle moes die werksaamhede van die gemeentes stimuleer. Jansen (1952:187) wys daarop dat vakante gemeentes in 'n klassis in 'preekringe' verenig is, wat moes reël dat erkende predikante aan hierdie gemeentes die Woord bedien. Anders as in die Nederlandse Hervormde Kerk van die negentiende eeu het hierdie ringe egter nie predikantringe met ' $n$ invloed op die regering van die gemeentes geword nie. Hulle was nie soos die Hervormde predikantringe wat die klasses mettertyd in hulle regering van die betrokke gemeentes uitgehol of 'teruggedwongen' het, sodat die klasses net een maal per jaar - in plaas van 4 keer en meer - vanweë 'n verskraalde behoefte moes vergader. Vir Jansen (1952:187) kon hierdie predikantringe in die Hervormde Kerk nie kerkvergaderings gewees het wat bindende besluite geneem het nie: hulle was niks meer as 'particuliere conferenties' wat adviese gegee het nie.

Die eerste Algemene Kerkvergadering of Sinode van die NGK, die Kaapse Sinode van 1824, verruil die benaming klassis egter vir ring (NGK 1824:7). Daarmee verdwyn die woord, klassis, uit die NGK-woordeskat en word die funksie hiervan aan die ring gegee. Die NGK neem die benaming, ring, direk uit die Nederlandse Hervormde Kerk se Algemene Reglement van 1816 oor. $^{2}$ Hierdie skuif kom ten spyte daarvan dat die NGK-gemeentes aan die Kaap vanaf hulle ontstaan by - let wel - die Klassis van Amsterdam van die ou Gereformeerde Kerk in Nederland, ingedeel was (Kleynhans s.a.:13). Dit is verder opvallend dat die NGK ook die term ringsbestuur ontwikkel het - na aanleiding van die Nederlandse Hervormde 'klassikale bestuur'.'nRingsbestuur se samestelling en taak word dus in die wette en bepalings van die NGK gereël (NGK in Zuid-Afrika 1881:33; Strauss 1995a:430).

2.Verskeie navorsers wys - met voorbeelde - op die direkte verband tussen die Algemene Reglement van 1816 van die Nederlandse Hervormde Kerk en die Algemene Reglement van 1824 van die Kaapse NGK (let ook op dieselfde naam Strauss 1995b:548). 'n Band wat gedeeltelik verklaar waarom verenigingsdenke of kollegialisme met ' $n$ rewolusionêr-humanistiese ondertoon ook ' $n$ rol in die keuse van die destydse NGK gespeel het vir begrippe soos 'ringsbestuur' en die sinode as sy 'hoogste directie'. Dit is begrippe wat vreemd is aan die anti-hiërargiese beginsel vir vergaterings in . Dit is begrippe wat vreemd is aan die anti-hierargiese beginse vir vergaderings in die gereformeerde kerkregering. In sy verslag van die eerste Sinode van die NGK (genoem die Algemene Kerkvergadering van 1824) aan sy opdraggewer, die Kaapse goewerneur, stel J. A. Truter, een van die kommissarissepolitiek op die sinode, dit soos volg:

the synod chiefly followed the rules laid down for the Reformed Church in Holland after the conclusion of the peace in 1815, with such modifications and alterations as the local circumstances of the Colony rendered necessary ... (NGK 1824:311)
Teen hierdie historiese agtergrond ondersoek hierdie artikel die taak van die klassis in die Nederlandse gereformeerde of Dordtse tradisie. Om die artikel te rig én die stof binne die bestek van een artikel af te handel, word die opdrag van die klassis tot drie resente kerkordes in hierdie tradisie beperk, uitgelig en ontleed, naamlik die kerkordes van die NG Kerk (NGKO), die Gereformeerde Kerke in Suid-Afrika (GKSAKO) en die Christian Reformed Church in Noord-Amerika (CRC-KO). Hierdie drie kerke probeer eksplisiet gestalte aan die beginsels gee wat in die Nederlandse kerkordelike tradisie soos die DKO vergestalt is en hulle was ook vir jare senior vennote in die gewese Gereformeerde Ekumeniese Raad (GER).

Die kerkregtelike posisie van die klassis word ontleed en daarna - soos gerig op die naburige gemeentes in sy gebied ook die kern van sy opdrag, naamlik kerkvisitasie. As benamings word met klassis volstaan wat histories kortliks verduidelik word, terwyl kerkvisitasie by die bespreking daarvan duideliker sal word.

\section{Ontstaan van die klassis}

Die woord, klassis, is van die Griekse benaming, 'klasis' of 'klésis', afgelei en die werkwoord is 'kalein'. Letterlik beteken dit om byeen te roep. In die latere Latyn kry die woord ook die betekenis van 'n 'corpus' of 'collegium' (liggaam of instelling van gelykes). In die Nederlandse gereformeerde tradisie word dit 'n aanduiding vir 'n groep naburige kerke of gemeentes, terwyl die Gereformeerde Kerk van Frankryk die woord vir die aanduiding van 'n vergadering predikante gebruik het. Sedert die Konvent van Wesel in 1568 het die Nederlandse Gereformeerde Kerke die woord as die naam vir 'n vergadering van naburige kerke of gemeentes deur middel van hulle afgevaardigdes, gebruik (Bouwman 1985:126).

Van den Broeke (2010:18-19) oordeel dat die ontstaan van die klassis as ' $n$ vergadering van naburige kerke voorafgegaan is deur byeenkomste van predikante, teoloë of doktore en ander kerkraadslede uit naburige gemeentes. In OosFrieslandhetaLascodieterm coetusvirpredikantsvergaderings ingevoer, ' $n$ term wat hy aan soortgelyke vergaderings in Genève, Zürich en Keulen ontleen het. Soos ander reformatore (gereformeerdes of hervormers) was a Lasco nie gelukkig met die Lutherse superintendent ('n kerklike inspekteur) nie, omdat dit volgens hom episkopaals en hiërargies was. By hom het die coetus die take van hierdie superintendent oorgeneem en as 'n vergadering van gelykes pastoraal hanteer, naamlik die opsig oor jong predikante, die begeleiding van die herders en leraars en die bewaring van die suiwer leer. A Lasco se coetus het elke Maandag - van Pase tot die einde van September - vergader en die tug- en appèlsake van die predikante, die eksaminering van opkomende dominees en die bespreking van leerstellige kwessies behartig. Na sy ontsnapping na Londen het a Lasco in 1560 sy coetus daar gevestig. Dit het die naam geword van 'n maandelikse vergadering van predikante, ouderlinge en diakens van die Nederlandse, Franse en Italiaanse 
gereformeerde gemeentes in Londen. Die coetus het veral aandag gegee aan eenvormigheid in die tug en die organisasie.

Die gereformeerde Sinode van Parys van 1559 gebruik in sy Discipline Ecclesiastique of kerkorde die colloque as 'n weeklikse vergadering van predikante, en later van predikante, ouderlinge en diakens. In die suide van Nederland ontwikkel die Sinodes onder die kruis in 1563-1566 provinsiale konsilies of 'n 'Concile Provincial' as 'n vergadering wat volg op die vergadering van die kerkraad. Hierna het die Konvent van Wesel (1568), die Nasionale Sinodes van Emden (1571), Dordrecht (1578), Middelburg (1581), Den Haag (1586) en Dordrecht (1618-1619) in hulle kerkordes die omskrywing, ontstaan en ontwikkeling van die klassis oorgeneem. Jansen (1952:186; sien ook Van den Broeke 2010:21) wys daarop dat die Sinodes onder die kruis self nie veel meer as die latere klasses was nie. Bouwman (1985:125) noem die vergadering tussen die kerkraad en die sinode in die Franse Gereformeerde Kerk tot 1572, toe hierdie kerk die klassis by sy Nederlandse eweknie oorneem, nie 'n vergadering van kerke of gemeentes nie, maar van persone of ampsdraers.

Emden (1571) stel die klassis in die Vaderlandse Gereformeerde Kerk in Nederland prakties in werking. In sy acta, artikel 7, bepaal hierdie Sinode dat daar elke drie of ses maande 'n 'classikale versameling' van gemeentes gehou word soos die 'gelegenheid en noodruftigheid' van die kerke of gemeentes dit vereis (aangehaal in Pont 1981:104).

Vir Emden is die ontwikkeling van die klassis noodsaaklik omdat die Gereformeerde Kerk in Nederland tot 1572 'n kwesbaarheid onder vyandige staatsdruk en 'n oorgang in hulle gereformeerde karakter beleef het. Hierdie twee faktore bedreig die bestendigheid van die kerke of gemeentes. Die klassis kan die eenheid en krag (in geloofsoortuiging) van die gereformeerde kerke konsolideer, die gemeentes help om mekaar as kerke by te staan, die vryheid van die gemeentes en lidmate teenoor willekeurige ampsdraers handhaaf en eerbied vir die bepalings van die Woord en die tug in die gemeentes bevorder (Bouwman 1985:126-127; Van den Broeke 2010:23). Dus, die klassis kan die hartaar van die kerk wees, à la Kleynhans.

\section{Die klassis in die Nederlandse gereformeerde tradsie van die sestiende en sewentiende eeu}

Emden gee rigting aan die ontwikkeling van die klassis in die Nederlandse gereformeerde kerklike tradisie. Die klassis is naamlik ' $n$ vergadering van naburige gemeentes deur hulle verteenwoordigers - nie van individue of ampsdraers nie wat verantwoordelikheid vir mekaar neem. In hierdie tradisie word die klassis 'n meerdere vergadering waarby die begrip meerdere nie op meer of hoër gesag dui nie, maar op méér gemeentes wat deur hulle kerkrade afvaardig. ${ }^{3}$ 'n

3.Bouwman (1985:136) wystereg daarop dat diewerk van die klassis nie'nvoortsetting van die ampswerk in diem en , ' wees wat hierdie soort werk goed kan doen. " $n$ Ampsdraer kan sy amp volledig beoefen sonder om ooit na' $n$ meerdere vergadering afgevaardig te word. Ampswerk is - kort gesê - gemeentewerk binne die gemeente as ' $n$ komplete kerk.
Meerdere vergadering vertoon die volgende drie hoofeienskappe: dit moet inpas by die beginsels of konstantes vir gereformeerde kerkregering; dit moet die eie aard en taak van die klassis erken; en dit moet oortuigend toon dat die klassis nie die werk van die betrokke gemeentes moet oorneem nie.

Die beginsels vir gereformeerde kerkregering dui op die antihiërargiese beginsel waardeur ampsdraers en gemeentes (afgesien van grootte of vermoë) as gelykes met gelyke verteenwoordiging in kerkregeervergaderings funksioneer ('n navolging van die anti-hiërargiese beginsel in artikel 1 van die Sinode van Emden in 1571 soos geneem uit artikel 1 van die Discipline Ecclesiastique van die eerste gereformeerde sinode, die Sinode van Parys in 1559; Strauss 1989:2). Die eie aard en taak van die klassis is dat dit pastoraal versorgend teenoor die gemeentes waaruit dit bestaan, moet wees. Hierdie taak moet elke gemeente selfstandig met sy eie diskresie verrig. Laasgenoemde is haalbaar indien die meerdere vergadering nie 'n oorname nie, maar' $n$ herstel van die selfstandigheid en welsyn van die gemeente as komplete kerk is (NGK-VS 2013:18; Van den Broeke 2010:23; vgl. ook Emden se artikel 42 soos aangehaal in Pont 1981:108). ${ }^{4}$

Agtereenvolgende Nederlandse Sinodes verdeel die gereformeerde kerkverband in klasses. By die Sinode van Middelburg (1581) was daar reeds 30 klasses (Van den Broeke 2010:23). Die Nasionale Sinode van Dordrecht (1618-1619) met sy DKO wat as die laaste sinode in die Nederlandse Gereformeerde Kerk van die sestiende en sewentiende eeue wye navolging in gereformeerde kerke binne en buite Nederland vind, vuur in die bepaling van die inhoud van die klassis voorlopig die laaste salvo in hierdie tradisie.

Bepalings vir die klassis kom in artikel 41 en 44 van die DKO voor soos hieronder bespreek word.

Artikel 41 konsentreer op die samestelling van die klassis en die voorsitter se rondvraag tydens die vergadering aan die verteenwoordigers van die gemeentes oor die welstand in hulle betrokke gemeentes. Die artikel begin met die, nou alreeds geykte, woorde dat die klassis 'bestaan uit genabuurde kerken'. Die DKO kies dus vir die begrip dat meerdere vergaderings eerder vergaderings van meer kerke en nie van individue is nie. Hierdie beginsel werk deur in die samestelling en die taak van die klassis.

Vir die samestelling van die klassis maak die DKO vir een predikant en ouderling van elke betrokke gemeente voorsiening. Hulle is afgevaardigdes wat met 'n 'behoorlijke credentie' (geloofsbriewe) van hulle kerkraad aanmeld. Die rondvraag van die voorsitter aan elke gemeente geskied aan die hand van vrae wat uit die taak van die klassis spruit, naamlik oor die onderlinge versorging van die gemeentes

4.Van den Broeke (2010) oordeel dat Emden se verdeling van die Nederlandse Gereformeerde Kerk in klasses 'n pastoraal-organisatoriese karakter dra.

The synod had to deal with a young church that was in a process of becoming The synod had to deal with a young church that was in a process of becoming
Calvinist. It wanted to bring together scattered, young and vulnerable Calvinist. It wanted to bring together scattered, young

congregations into a regional body and maintain it. (bl. 23)
Feitlik alle gemeentes in die kerkverband is daarom in klasses verdeel soos weerspieël in artikels 11 en 12 (aangehaal in Pont 1981:104). 
van mekaar. As 'n anti-hiërargiese maatreël mag dieselfde predikant nie by twee agtereenvolgende klasses as voorsitter optree nie.

In sy rondvraag gebruik die voorsitter die volgende vrae: Word vergaderings van die kerkraad gereeld gehou?; Word die kerklike tug in die gemeente gehandhaaf?; Word die armes en die skole versorg en is daar iets waarmee die klassis die gemeente kan help? Uit 'n kerklike hoek beskou, gaan dit hier oor die onderlinge versorging van die gemeentes in die klassis. Hierdie versorging moet pastoraal van aard wees: versorgend en liefdevol sonder om doekies om te draai of probleme te verdoesel. Indien 'n valse beeld van die gemeente aan die klasses voorgehou word, is die rondvraag uiteraard nutteloos en sy afgevaardigdes kerklik ongeloofwaardig.

Wat vir hierdie artikel ten opsigte van DKO 1619 belangrik is, is sy bepalings vir kerkvisitasie aan elke gemeente in die klassis deur visitatore soos deur die klassis aangewys en in artikel 44 vervat is.

\section{Die DKO: Kerkvisitasie}

Volgens DKO 1619, artikel 44 het kerkvisitasie die volgende behels:'n navraag na en stimulering van (toesien van) die getroue waarneming of uitlewing van hulle ampte deur die leraars, kerkraadslede en onderwysers of 'schoolmeesters'; die handhawing van die suiwer leer deur hierdie ampsdraers; hulle getrouheid in alles aan die kerkorde; hulle bydrae tot die troos en stigting van die gemeente en veral die jeug met woord en daad; en hulle broederlike vermaning, raad en daad in die opbou van die gemeente en die skool (Pont 1981:181).

Opvallend is die klem op die gereformeerde belydenis, die kerkorde en die versorging van die gemeente deur die kerklike tug as 'n pastorale handeling ('n toegespitsde bediening van die Woord). 'n Klem wat beskou word as gereformeerd. Daarby is kerkvisitasie ' $n$ belangrike arm van die ring om sy tweeledige taak soos by Emden in 1571 gevisualiseer, uit te voer, naamlik die uitbou van die verenigde $\mathrm{krag}$ van die gemeentes teenoor vyandige staatsoptrede, én die stabilisering van hulle gereformeerde karakter. Voeg hierby ook die DKO se uitgesproke kerklike betrokkenheid by skoolonderwys in Nederland as 'n teokratiese verbondsgemeenskap of eenheidsgemeenskap in die sewentiende eeu (Strauss 2010:126).

Hierdie oogmerke vir kerkvisitasie word nagejaag sonder dat die visitasiekommissie soos getaak deur die klassis, die kerkregeerbevoegdhede van die klassis oorneem. Die waarnemings en gevolgtrekkings van die kommissie bly dié van 'n kommissie van die klassis wat slegs amptelike sanksie of status kry indien dit die besluite van die klassis word. Kort gesê: teen die reformatoriese agtergrond van Dordt is die visitasiekommissie nie 'n pouslik-hiërargiese kommissie van 'n klein groepie nie; nie ' $n$ kommissietjie wat op eie insisiatief in gemeentesake ingryp en daaroor heers nie, maar 'n pastoraal-adviserende kommissie wat by wyse van 'n ooreenkoms (soos in die kerkorde verwoord is) tussen die gemeentes optree. Dit is 'n adviserende kommissie wat die volledige, selfstandige kerkwees van die gemeente moet stimuleer; 'n kommissie wat die kerkraad en die gemeente nie met kerklike gesag moet probeer dwing nie, maar deur Woordgebonde advies pastoraal moet oortuig; 'n kommissie wat die norm, ecclesia reformata, semper reformanda, eerbiedig en uitleef (Strauss 2010:16).

So beskou is die visitasiekommissie 'n belangrike arm van die klassis in sy pastorale versorging van die gemeentes binne sy gebied of 'ressort'; 'n arm van die betrokke gemeentes in hulle onderlinge sorg vir mekaar. Boonop lê daar 'n aantoonbare band tussen die Nederlandse Emden en Dordt ten opsigte van die eie, selfstandige taak van die klassis. Die DKO is immers net vir die Nederlandse Gereformeerde Kerk deur die Nederlandse afgevaardigdes na die Dordtse Sinode van 1618-1619 gefinaliseer. Dit het plaasgevind nadat die Dordtse Leerreëls, as die derde van die Drie Formuliere van Eenheid, saam met Engelse, Duitse en Switserse afgevaardigdes opgestel is en die Switserse afgevaardigdes die vergadering verlaat het (Kuiper 1995:268; Strauss 2010:7).

In die lig hiervan verbaas DKO artikel 44 nie met sy vereistes vir geskikte visitatore nie. Die visitatore moet twee van die 'oudste, ervarenste en geschikste' bedienaars van die Woord uit die klassis wees - bedienaars uit die stad én die platteland indien die klassis sodanige gemeentes in sy midde het (Pont 1981:181). Van ouderlinge as visitatore is daar nie sprake nie, omdat die visitasiekommissie nie 'n anti-hiërargiese kerkregeerkommissie is nie en aangesien sy adviese Woordgebonde moet wees. Adviese moet kom van ervare bedienaars van die Woord met ervaring van die sinvolle werking van gemeentes. Juis omdat die visitasiekommissie nie 'n kerkregeerkommissie is nie, word visitatore nie veronderstel om hiërargies oor die ander lede van die klassis te heers nie. Die uitsprake van die visitatore dra nie meer gewig as die uitspraak van enige ander predikant in die klassis nie. Vistatore is nie kerklike superintendente of gesagvolle kerklike inspekteurs wat die klassis net as 'n onmondige lanseerbasis vir hulle bevindings gebruik nie.

Die klassis se hantering van 'n bepaalde visitasieverslag weerspieël ook die erns waarmee hy sy versorgingstaak van die gemeente opneem. Hierdie is 'n verslag waaroor die gemeente eerstehands ingelig moet word en waarby dieselfde gemeente, deur middel van sy afgevaardigdes, betrokke moet wees. Kerklik-pastoraal praat ons immers nie óór mekaar nie, maar direk mét mekaar. Juis omdat die kerk homself deur middel van (geloofs-) oortuiging uit- en opbou en nie deur fisiese dwang nie, praat én besluit ons in oorleg met mekaar. So kom gemeentes tot 'n eenheid in oortuiging(s) wat Woordgebonde moet wees en daarom alleen van die Gees kom en tot opbou van die kerk is (Strauss 2010:83).

Soos in die vooruitsig gestel, word nou oorgegaan tot die ontleding van die klassis en kerkvisitasie in drie kerkordes wat, elkeen op sy eie manier en selferkend, in die verlengde van die Dordts-gereformeerde tradisie lê, te wete die 
kerkordes van die NG Kerk (NGK), die Gereformeerde Kerke in Suid-Afrika (GKSA) en die Christian Reformed Church in North America (CRC; Strauss 2010:7).

\section{Die NG Kerkorde, die ring en kerkvisitasie}

Die NGKO (2013:8) bepaal dat die ring uit een bedienaar van die Woord en een ouderling of diaken van elke gemeente binne die ringsgebied saamgestel word. Oppervlakkig gelees, gee hierdie bepaling erkenning aan die gelykheid van gemeentes by die samestelling van die ring. ' $n$ Gelykheid wat egter nie ten opsigte van die ampte van ouderling en diaken erken word nie. Daar kan immers meer ouderlinge as diakens, of omgekeerd, op die ring sitting neem. Boonop word daar aan óf die ouderlinge óf die diakens, mits daar van albei ampte op die ring plaasneem, nie gelykheid teenoor die bedienaars gewaarborg nie. Teenstrydig hiermee word die beginsel van die gelykheid van die gemeentes erken wanneer 'n ouderling of diaken tydens 'n vakature in die amp van die bedienaar, in die vakature na die ring afgevaardig kan word. Wat ook opval, is dat sy ampsdraers die gemeentes kan verteenwoordig, maar nie belydende nie-ampsdraers met ervaring van byvoorbeeld kerkvisitasie nie - asof die ring amps- of gemeentewerk dupliseer en sy lede nie en ook asof die ampsdraers in die gemeente nie ook op grond van bekwaamheid vir die take in die ring aangewys moet word nie (vgl standpunt by Strauss 2004:664-673).

In 'n volgende bepaling oor die samestelling van die ring (NGKO 2013:8) word beweer dat 'n gemeente met meer as een predikant die reg het om al sy predikante, vergesel van 'n gelyke aantal ouderlinge en diakens na die ring af te vaardig indien die betrokke sinode sodanig besluit. Hiermee word die gelykheid van die gemeentes of die ampte - die antihiërargiese beginsel - in gereformeerde kerke nié gehonoreer nie. In plaas van 'n vergadering van gemeentes word die ring 'n vergadering van predikante met 'n willekeurige aantal ouderlinge of diakens. 'n Ou NGK-kwaal loer ook oor die skouer indien sinodes toegelaat word om bepalings in kerkordelike sake te maak wat by die Algemene Sinode lê. Hierdie is 'n kwaal wat vanaf die eerste Algemene Sinode in 1962 kom en tot te veel kerkordebepalings vir gemeentes aanleiding gee (Jonker 1960:35; Strauss 2017:9). 'n Kundige buitestander kan met reg sy kop skud oor hierdie gebrek aan kerkregtelik verantwoorde lyne.

In sy bepaling van die redes vir die bestaan van die ring, skep die NGKO (2013) 'n nie-tradisionele Nederlandsgereformeerde indruk, Die NGKO 2013, artikel 29 volstaan met die volgende as redes vir die ring: 'die uitdrukking van die kerkverband en ... behoorlike kerklike dissipline'. Hierdie nie-tradisionele indruk word versterk wanneer 'n volgende artikel die werksaamhede van die ring bepaal.

In die lig van hierdie historiese skets is dit aanvanklik bemoedigend dat kerkvisitasie en opsig oor die gemeentes sodat hulle hulle roeping nakom, bo-aan die lysie staan (NGKO 2013:8, 9). Die probleem is egter dat kerkvisitasie as 'n ondersteunende, adviserende pastorale handeling wat navraag na die welsyn van die gemeentes doen, nie sonder meer dissiplinêr van aard is nie. Opsig oor gemeentes is ook nie noodwendig ' $n$ dissiplinêre handeling nie. Daarby is hierdie twee belangrike, uitstaande take van die ring nie ongekwalifiseerd 'n uitdrukking eie aan die kerkverband nie. Kommer oor die welsyn van gemeentes kan bloot uit 'n algemene Christelike broederskap spruit. Dieselfde bepaling ontbreek om die een of ander rede by die ander meerdere vergaderings in die NGKO, naamlik die NGK-sinodes en die Algemene Sinode. Waarom word die ring hiervoor uitgesonder? Kommunikeer hierdie bepaling dalk twyfel oor die noodsaaklikheid van die agenda van die ring? (NGKO 2013:9-12).

In sy bepaling van die take van die ring konsentreer die NGKO (201)3, artikel 31 naas kerkvisitasie en 'opsig oor die gemeentes' op meer administratiewe take van die ring soos die stigting van gemeentes met grense, 'n ongekwalifiseerde hulp aan kerkrade, die hantering van appèlle en, as 'n uitsondering hierop, die formele tug oor ampsdraers (NGKO 2013:9).

Wat die veelheid én innerlike teenstrydighede van hierdie begrippe versterk, is die feit dat die bepalings vir die inhoud van kerkvisitasie in die NGK aan die sinodes - aan elke (streek-) sinode - oorgelaat word. 'n Greep uit die bepalings van sinodes bevestig hierdie veelheid.

\section{NGK-sinodes, die ring en kerkvisitasie}

Vir die visitasiekommissie volstaan die Sinode van WesKaapland met twee lede van die ringskommissie en een persoon aangewys deur Communitas ${ }^{5}$ by die Teologiese Fakulteit van Stellenbosch (NGK-WK 2015:45). Die herkoms van hierdie kommissie dui op 'n keuse vir ervaring, leierskap en kundigheid. Die werksaamhede van die ring word egter in 'n reglement vervat wat die NGKO moet aanvul. So bly die eerste NGKO, NGKO 1964, nie staan nie. Jonker (1960:36) bestempel hierdie kerkorde as 'enkele groot lyne ... waarin die kerke (samestellende sinodes en gemeentes) in vryheid en verantwoordelikheid met die Bybel in die hand mag beweeg'. 'n Reglement dra nie dieselfde gesag as die kerkorde nie, maar is tog bindend. By die Sinode van Noord-Kaapland ontbreek kerkvisitasie by die werksaamhede van die ring. Hierdie Sinode volstaan met die NGKO 2013 wat net na kerkvisitasie verwys en die inhoud van die saak aan die sinodes en ringe oorlaat (NGK-NK 2016:19).

In 'n sinodebesluit by die NGKO 2013 se artikels oor die ring, bepaal NGK-VS dat ' $n$ visitasiekommissie uit minstens twee lede moet bestaan. As riglyne vir so 'n kommissie word afwisseling, kontinuïteit, ervaring en bekwaamheid neergelê. Hierdie kommissie het die oog op die pastorale versorging en welsyn van die gemeente. In die proses moet daar na die leer en lewe van die gemeente waaronder die ampswerk, die 
handhawing van die gereformeerde leer, die nakoming van die $\mathrm{NGKO}^{6}$ en die besluite van meerdere vergaderings én die op- en uitbou van die gemeente gekyk word (NGK-VS 2013:18). Hiermee kom hierdie Sinode naby aan die beginsel van 'n eie taak soos vereis word van die klassis, of in hierdie geval, die ring.

Die Kerkorde van die NGK van Natal verwys net na kerkvisitasie as persoonlike visitasie (NGK-Ntl 1999:18). Op sy beurt bepaal die Sinode van die NG Kerk in Namibië dat die beginsels van afwisseling en kontinuiteit by die samestelling van die visitasiekommissie geld en dat die ring die inhoud van die visitasie moet bepaal (NGK-Nam 1999:26). Sy erkenning van die selfstandigheid van die ring om die inhoud van visitasie te bepaal, moet verwelkom word. Die konstante of uitgangspunt dat visitasie 'n pastorale versorging van die gemeente in al sy fasette deur die ring moet wees, word egter geïgnoreer. Hoewel die selfstandigheid van die ring erken moet word, bring hierdie konstante mee dat die aard en inhoud van die visitasie uit 'n gereformeerde hoek nie debatteerbaar is of opnuut deur ringe bepaal moet word nie.

In die Noordelike Sinode gee die kerkorde van die NGK-N geen bepalings vir die samestelling van die visitasiekommissie nie. Die visitasie moet egter oor byna alles van die gemeente handel, naamlilk die bedieningstrategie, finansiële beplanning, diensverhoudings met amptenare, gemeentebou, eredienste, die jeug, barmhartigheid en sending (NGK-N 2012:41, 42). Hierdie elemente maak egter nie vir die gereformeerde leer, die gehoorsaming van die kerkorde en besluite van meerdere vergaderings voorsiening nie. Soos by ander NGK-sinodes en kerkvisitasie raak die punte nie belydenis- en histories bewese aktualiteite van 'n gereformeerde aard nie. Die Oostelike Sinode vaar in dieselfde rigting. Hier word die visitasie van die 'familie' wat mekaar versorg, oorgelaat aan die konsulent en 'n ouderling van die eie gemeente (NGK-O 2016:39). Faktore soos ervaring en kundigheid buig voor ' $n$ familieband en die gelykheid van die dominee-visitatore en ander NGKleraars. Die metafoor van 'n familie omvorm kerkvisitasie as 'n pastorale versorging met aanvoeling en kundigheid tot ' $n$ famliebyeenkoms. Dieselfde vae rigting oor die inhoud van kerkvisitasie kom by die NGK se Sinode van Wes-Transvaal voor. Hier gaan dit oor 'n navraag na die aanbidding, feesviering, koinonia, didache, diakonia en uitbou van die gemeente (NGK-WT 2005:23). Hierdie sake vir kerkvisitasie word met nie-konkrete name en vae begrippe aangedui. Daarmee word ringsvisitasie verwond in die lewe van 'n gemeente ingedra.

Uit hierdie kort greep blyk dit dat daar in die NGK nie konsensus oor die kerkvisitasietaak van die ring as 'n pastoraal versorgende handeling van belydenisgebonde gereformeerde gemeentes is nie. Die gevaar bestaan dat ringe in die NGK, as die hartaar van die kerkverband, kan ontspoor en futlose vergaderings word wat telkens na die sin en rede vir hulle bestaan soek. Die bepaling van die NGKO (2013) dat ringe die kerkverband uitdruk, kan met sinvolle kerkvisitasie meer stabiel en beter vergestalt word. Meer nog, met 'n pastorale, stimulerende benadering kan kerkvisitasie kerklike dissipline - die tweede rede vir die bestaan van die ring volgens NGKO (2013) - by voorbaat voorkom.

By die Gereformeerde Kerke in Suid-Afrika (GKSA) en die Christian Reformed Church in Noord-Amerika (CRC) is daar net een sinode wat kerkordelike bepalings maak, naamlik die breedste sinode (ten opsigte van die gemeentes wat betrokke is) of ' $n$ meerdere vergadering.

\section{DIE GKSA-KO en kerkvisitasie}

Die GKSA-KO noem die klassis 'n vergadering van 'naburige kerke' wat elkeen 'n bedienaar van die Woord en 'n ouderling afvaardig. Waar daar nie ' $n$ bedienaar in die gemeente is nie, kan hierdie 'kerk' 'n tweede ouderling afvaardig (GKSA-KO (2003), artikel 41). By die vergadering van die klassis moet die voorsitter of praeses steeds rondvra:

of die kerke kerkvergaderings hou, of die kerklike tug uitgeoefen word, of die armes en die skole versorg word, en of daar iets is waarin die kerk die oordeel en hulp van die klassis vir sy regte bestuur nodig het. (bl. 179-180)

Dieselfde bedienaar mag nie op twee agtereenvolgende vergaderings as voorsitter aangewys word nie (Van der Linde 1983:156; Visser 1999:185). Die GKSA-KO se navolging van die DKO is byna woord vir woord. Die enigste wysiging raak die laaste taak van die klassis, naamlik oordeel en hulp aan 'n bepaalde gemeente.

Met die samestelling van die klassis toon die GKSA dat dit 'n vergadering van meer kerke of gemeentes as gelykes is. Antihiërargies vaardig die samestellende gemeentes gelyk af, omdat hulle elkeen volledig kerk is. Elkeen is dus 'n kerk waarin die merktekens van die ware kerk volgens die Nederlandse Geloofsbelydenis - in beginsel - moontlik én sigbaar is: die suiwere prediking van die Woord, die regte bediening van die sakramente en die gebruik van die kerklike tug om die sondes te straf (NGK-Uitgewers 1982:29). Hierdie drie geestelike oorwegings bepaal hulle kerkwees en strukturele gelykheid met ander gemeentes - nie hulle getalle of inkomste nie. Hulle gelykheid lê in die begrip of die beginsel van 'n strukturele gelykwaardigheid opgesluit. Daarby gaan dit hier ook om ampsgelykheid wat die bedienaars en ouderlinge betref - met geen diakens wat die saak bemoeilik nie. Dit is 'n ampsgelykheid wat uit die bekleding van die amp deur 'n gelowige mens spruit en nie 'n gelykheid in vermoë of gawes nie, maar in hulle gelowig menswees - in hierdie sin dus ook 'n strukturele of antropologiese gelykwaardigheid.

Die rondvraag van die voorsitter is ook tipies Dordts. Dieselfde tendens word by die samestelling van die visitasiekommissie voortgesit wat dan alle 'kerke' van die klassis gereeld moet besoek. Hierdie kommissie moet uit twee van die oudste, mees ervare en geskikste bedienaars 
van die Woord in die klassis bestaan. Hulle moet by die gemeentes vasstel of die ampsdraers hulle pligte getrou nakom, die suiwerheid van die leer handhaaf, die Kerkorde 'in alles' onderhou, asook die stigting van die gemeente en die onderwys van die jeug bevorder. So moet hulle met raad en daad die vrede, opbou en belange van die kerk of die gemeente bevorder om sodoende tugstappe te voorkom (Van der Linde 1983:162; Visser 1999:192).

Weer is die saak en woordkeuse van die GKSA-KO hierin Dordts. Wat meer is, die GKSA-KO plaas dieselfde sake onder dieselfde artikelnommers as die DKO. Daarby handhaaf die GKSA-KO 'n soberheid in sy bepalings vir die klassis en kerkvisitasie -'n soberheid wat nie oorreglementeer nie, maar ook nie te min bepaal nie (Strauss 2017). Sy aanpak verhoed dat klasses en (partikuliere of streek-) sinodes soos by die NGK, die inhoud van kerkvisitasie moet bepaal. Om sy kontinuïteit met die DKO verder te illustreer, bring die GKSA-KO die samestelling en opdrag of taak van die klassis ook onder onderskeidelik artikel 41 en 44 tuis. Hiermee loop die GKSA kerkordelik die Nederlandse gereformeerde DKOpad met geringe aangepasde woordwysigings. Wat van die DKO oor sy prinsipiële of konstante uitgangspunte gesê is, is ook op die GKSA-KO van toepassing.

Die GKSA-KO gee in die een-en-twintigste eeu ook nie aan die visitatore die gesag van kerklike superentendente of hiërargies hoër bedienaars van die Woord nie. Wat wel by hom ontbreek, is die resente ontwikkeling in die NGK om kerkvisitasie as 'n pastorale handeling te kwalifiseer. Pastorale advies word in die GKSA-KO nie in die plek van die klassis met dieselfde bindende krag as die besluite van die klassis oorgedra nie. Pastorale advies sal juis sodoende nie formeel en klinies, onkerklik en onpersoonlik oorkom nie, maar juis geestelik bind en so die kerkverband as 'n geloofsverband versterk. Sodanige pastorale advies sal juis in moderne tye met gesindheid, argument en redelikheid oortuig en nie met ' $n$ klinies-korrekte en kille formele optrede nie. As 'n instelling van die geloof vir Christengelowiges of -oortuigdes wil die kerk teensinniges immers oortuig en nie emosioneel dwing of oordonder nie.

\section{Die CRC-KO en kerkvisitasie}

Soos die NGKO het die CRC-KO aantoonbare bande met die geestelike gereedskap van die DKO. Hierdie bande lê nie soseer in 'n byna woordelikse gebruik van die formulerings van die bepalings van die DKO soos in die GKSA-KO nie, maar in die CRC-KO se aansluiting by die konstantes of uitgangspunte van die DKO (Engelhard \& Hofman 2001:13, 14).

Die CRC-KO se samestelling van die klasses stem met dié van die GKSA-KO ooreen: 'n bedienaar en ouderling van elke samestellende gemeente en 'n ouderling, indien die amp van die bedienaar vakant is. Volgens die CRC-KO mag alle ander ampsdraers van die samestellende gemeentes die klassis egter in adviserende hoedanigheid bywoon (Engelhardt \& Hofman 2001:247).
Soos die DKO bepaal die CRC-KO ook dat die voorsitter van die klassis die afgevaardigdes van die gemeentes op die klassis by 'n rondvraag betrek. Hierdie rondvraag het ook 'n navraagna diegereeldeplaasvind vankerkraadsvergaderings, die uitoefening van kerklike dissipline, die diakonale sorg vir die behoeftiges, die bevordering van Christelike skoolonderwys en evangelisasie. Hierbenewens moet die voorsitter verneem of die gemeentes aan ander gemeentes kennis gee wanneer van hulle lidmate in daardie gemeentes intrek, of die gemeentes die kerkverband inlig oor lidmate wat hulle buite die bestaande gemeentes vestig, en of gemeentes ander CRC-lidmate as nuwe intrekkers in hulle eie gemeente ontvang en bedien (Engelhard \& Hofman 2001:253).

Vanuit die anti-hiërargiese beginsel bepaal die CRC-KO ook dat dieselfde voorsitter van die klassis nie twee maal agtermekaar mag dien nie (Van Dellen \& Monsma 1967:164; sien ook Engelhard \& Hofman 2001:248).

Net soos in die DKO en die GKSA-KO gee die CRC-KO ook opdragte aan die kerkvisitasiekommissie. Hierdie opdragte gaan oor inligting vir 'n behoorlike pastorale gesprek en staan in die verlengde van die DKO of die Dordtse kerkordelike tradisie: Voer die ampsdraers hulle take uit, word die gesonde leer gehandhaaf en die Kerkorde gehoorsaam ${ }^{7}$ en vind daar 'n opbou van die gemeente en 'n uitbreiding van God se koninkryk plaas? Boonop moet die visitatore vasstel of die onverskilliges in die gemeente vermaan, geadviseer en gehelp word. Die CRC-KO voeg twee bepalings vir visitatore by: hulle moet deurgaans daar wees vir advies aan die gemeentes en 'n skriftelike verslag van hulle besoek aan die klassis lewer (Engelhard \& Hofman 2001:257).

Aan die een kant bepaal die CRC-KO nie uitdruklik dat kerkvisitasie ' $n$ pastorale handeling is nie. Daar is geen aanduiding dat die skriftelike verslag pastoraal met die betrokke gemeente deurgepraat moet word nie. Indien die verslag net skriftelik of pro forma aan die klassis gelewer word, kan die ontbreking van 'n goeie gesprek met die gemeente en die klassis tot 'vormgodsdiens' lei. Aan die ander kant laat hierdie bepalings die klassis op die hartsake van die gemeentes konsentreer en maak dit die klassis die hartaar van kerkverband - à la Kleynhans.

Oor die visitasiekommissie is die CRC-KO baie direk. Die klassis moet ten minste een so 'n kommissie aanwys wat die betrokke gemeentes een maal per jaar besoek. Hierdie kommissie moet uit twee ervare en kundige ampsdraers én twee bedienaars van die Woord, of een bedienaar en een ouderling bestaan (Engelhard \& Hofman 2001:257).

Dat die CRC kerkvisitasie met erns benader, blyk uit die volgende twee waarnemings. Die eerste is die nugter waarneming van Engelhard en Hofman dat kerkvisitasie in

7.Van Dellen en Monsma (1967:172) oordeel dat'n kerkorde nie moet oorreglementeer nie. Hulle voer aan dat gehoorsaming van so 'n kerkorde vryheid van aksies ooplaat en nie alle ander opinies en metodes uitskakel nie. 
die CRC nie altyd sinvol en effektief is nie. Dit ontaard soms in 'n meganiese, vlugtige noodsaaklikheid. Tog skep dit goeie broederlike adviese en geleenthede om pastoraal-kerklik te groei. Die tweede is dat daar twee handleidings vir 'Conducting church visiting' deur die CRC-sinode ontwikkel het: die een kompileer die vrae wat gevra kan word en die ander is ' $n$ algemene gids vir visitasie (Engelhard \& Hofman 2001:159).

\section{Slot}

Die beginsel in ' $n$ gereformeerde kerkverband moet wees dat die klassis of die ring pastoraal-versorgend teenoor die gemeentes in sy gebied asook die naburige gemeentes, optree. Hierdie uitgangspunt bring mee dat die klassis op 'n hartsaak in die kerkverband, te wete die welsyn van die gemeentes, konsentreer. 'n Kerkverband is immers 'n verband van gemeentes as komplete kerke (Bavinck 1967:356; Bouwman 1985:100-101).

Dit alles impliseer dat kerkvisitasie in die hart van die klassis se werk lê. Kerkvisitasie deur 'n kommissie van ervare en kerkkundige bedienaars van die Woord as 'n pastorale handeling moet die gemeentes bou en nie afbreek nie. 'n Kerkverband is so sterk as wat die gemeentes is wat hierdie verband vorm. Die op- en uitbou van die kerk loop primêr deur die gemeente.

\section{Erkenning \\ Mededingende belange}

Die outeur verklaar dat hy geen finansiële of persoonlike verbintenis het met enige party wat hom nadelig kon beïnloed het in die skryf van hierdie artikel nie.

\section{Literatuurverwysings}

Bavinck, H., 1967, Gereformeerde dogmatiek, dl. 4, Kok, KampenBouwman, H., 1985 Gereformeerd kerkrecht, dl. 2, Kok, Kampen.

Engelhard, D.H. \& Hofman, L.J., 2001, Manual of Christian reformed church government, CRC Publications, Grand Rapids.

Gereformeerde Kerke in Suid-Afrika, 2003, 'Kerkorde', in Psalmboek: Die berymde en omgedigte Psalms en ander Skrifberymings in gebruik by die Gereformeerde Kerke in Suid-Afrika, bl. 171-188, NG Kerk-Uitgewers, Paarl Print, Paarl

GKSA-KO, kyk Gereformeerde Kerke in Suid-Afrika

Haitjema, T.L., 1951, Nederlands Hervormd kerkrecht, Callenbach, Nijkerk.

Jansen, J., 1952, Kerkorde der Gereformeerde Kerken, Kok, Kampen.

Jonker, W.D., 1960, 'Die bevoegdheid van die streeksinodes in die nuwe konsepkerkorde', Nederduitse Gereformeerde Teologiese Tydskrif Maart, 33-37.

Kleynhans, E.P.J., sa, Die kerkregtelike ontwikkeling van die Nederduits Gereformeerde Kerk in Suid-Afrika 1995-1962, s.n., s.l.
Kleynhans, E.P.J., 1985, Gereformeerde kerkreg, deel 3, NG Kerkboekhandel Transvaal, Pretoria.

Koffeman, L., 2009, Het goed recht van de kerk, Kok, Kampen.

Kruger, L.S., Du Plessis, H.L.M., Spoelstra, B. \& Spoelstra, T.T., 1966, Handleiding by die Kerkorde, Pro Rege, Potchefstroom.

Kuiper, B.K., 1995, The church in history, Eerdmans, Grand Rapids.

Nederduitse Gereformeerde Kerk, 1824, Handelinge Algemene Kerkvergadering, Kaapse Kerkargief S 1/1.

Nederduitse Gereformeerde Kerk, 1964, Kerkorde 1962, NG Kerk-Uitgewers, Kaapstad. Nederduitse Gereformeerde Kerk, 2012, Jaarboek van die NG Kerke, s.n., s.I.

Nederduitse Gereformeerde Kerk, 2013, Die Kerkorde, s.n., s.I.

Nederduitse Gereformeerde Kerk in Zuid-Afrika, 1881, Wetten en bepalingen, N.H. Marais, Kaapstad.

Nederduitse Gereformeerde Kerk Noordelike Sinode, 2012, Die Kerkorde, s.n., s.I. Nederduitse Gereformeerde Kerk Noord-Kaapland Sinode, 2016, Kerkorde, s.n., s.I. Nederduitse Gereformeerde Kerk Natal Sinode, 1999, Kerkorde, s.n., s.I. Nederduitse Gereformeerde Kerk Oostelike Sinode, 2016, Kerkorde, s.n., s.I. Nederduitse Gereformeerde Kerk Sinode Namibië, 1999, Kerkorde, s.n., s.I. Nederduitse Gereformeerde Kerk Sinode Vrystaat, 1999, Kerkorde, s.n., s.I. Nederduitse Gereformeerde Kerk Sinode Vrystaat, 2013, Kerkorde, s.n., s.I. Nederduitse Gereformeerde Kerk Sinode Wes-Kaapland, 2015, Kerkorde, s.n., s.I. Nederduitse Gereformeerde Kerk Sinode Wes-Transvaal, 2005, Kerkorde, s.n., s.I. NG Kerk-Uitgewers, 1982, Die drie Formuliere van Eenheid en ekumeniese belydenisse, NG Kerk-Uitgewers, Wellington.

NGK, kyk Nederduitse Gereformeerde Kerk

NGK-N, kyk Nederduitse Gereformeerde Kerk Noordelike Sinode NGKNam, kyk Nederduitse Gereformeerde Kerk Sinode Namibië NGK-NK, kyk Nederduitse Gereformeerde Kerk Noord-Kaapland Sinode NGK-Ntl, kyk Nederduitse Gereformeerde Kerk Natal Sinode NGK-O, kyk Nederduitse Gereformeerde Kerk Oostelike Sinode NGK-VS, kyk Nederduitse Gereformeerde Kerk Sinode Vrystaat NGK-WK, kyk Nederduitse Gereformeerde Kerk Sinode Wes-Kaapland NGK-WT, kyk Nederduitse Gereformeerde Kerk Sinode Wes-Transvaal NGKO, kyk Nederduitse Gereformeerde Kerk (2013)

Pont, A.D., 1981, Die historiese agtergronde van ons kerklike reg, HAUM, Pretoria.

Rutgers, F.L., 1971, De geldigheid van de oude kerkenordening der Nederlandsche gereformeerde kerken, Ton Bolland, Amsterdam.

Spoelstra, B., 1989, Gereformeerde kerkreg en kerkregering, Teologiese Skool, Hammanskraal.

Strauss, P.J., 1989, 'Geen kerk oor 'n ander ...', Acta Theologica 9(1), 1-14.

Strauss, P.J., 1995a, 'Die aktuarius in die Nederduitse Gereformeerde Kerk', NGTT 36(3), 421-436.

Strauss, P.J., 1995b, 'Die Algemene Sinodale Kommissie in die Nederduitse Gereformeerde Kerk', NGTT 36(4), 545-557.

Strauss, P.J., 2004, 'Nie-kerkraadslede op sinodes?', NGTT 45(3 \& 4), 664-671.

Strauss, P.J., 2010, Kerk en orde vandag, SunMedia, Bloemfontein https://doi. org/10.18820/9781920383213

Strauss, P.J., 2017, 'n Kerkorde in gereformeerde kerke toegepas op die Nederduitse Gereformeerde Kerkorde van 2013, s.n., s.I.

Van Dellen, I. \& Monsma, M., 1967, The revised church order commentary, Zondervan, Grand Rapids.

Van den Broeke, L., 2010, 'The history of the classis', in L. van den Broeke \& A.J. Janssen (eds.), A collegial bishop?, pp. 5-12, Eerdmans, Grand Rapids.

Van der Linde, G.P.L., 1983, Die kerkorde, Potchefstroomse Teologiese Publikasies, Potchefstroom.

Visser, J., 1999, Die kerkorde in praktyk, EFJ Snyman, Orkney. 